\title{
Catechesis and Episcopal Authority in the Life of Gregory Thaumaturgus
}

\author{
Allison L. Gray \\ Assistant Professor of Theology, St. Mary's University, San Antonio, TX, USA \\ agray7@stmarytx.edu
}

\begin{abstract}
In a seldom discussed episode from Gregory of Nyssa's Life of Gregory Thaumaturgus, the wonderworking bishop converts a pagan temple custodian using the written word and a miracle. Physical proofs seem essential for teaching this outsider about divine power. Yet in the very next episode the narrator praises Thaumaturgus for disregarding physical appearances and for keeping silent. A close reading of the Life 34-47 demonstrates that Gregory of Nyssa models, within the narrative, a progression from basic catechesis through signs to the more complex work of interpreting signs, making inferences from what is seen to that which remains unseen. Contextualizing this paradoxical sequence of Thaumaturgus vignettes in Cappadocian discussions of divine condescension and principles of fourth-century Christian paideia, I show that Gregory of Nyssa uses the juxtaposition between Thaumaturgus' teaching and conduct to model the flexible approach required for bishops to communicate the nature of divine power to varied audiences.
\end{abstract}

\section{Keywords}

bishops - biography - Cappadocians - catechesis - miracles - paideia

On his way to Neocaesarea, his future seat, Gregory Thaumaturgus stops at a local temple for an overnight stay. ${ }^{1}$ The demons who normally inhabit the

1 This episode begins in the De vita Gregorii Thaumaturgi 34 and runs through 41, following the numbering in Michael Slusser's 1998 English translation (M. Slusser, St. Gregory Thaumaturgus: Life and Works (Washington, D.C., 1998), corresponding to Heil 19-24). 
temple space and use their powers to offer oracular pronouncements find themselves driven out by Thaumaturgus' prayerful presence. Confronted by the enraged temple custodian, Thaumaturgus insists he not only repels the demons but in fact has the power to give them orders. First with a simple verbal command then with the power of the written word, Thaumaturgus commands the demons to return to and depart from the temple. The custodian is impressed and asks to learn more about Thaumaturgus' god, and the wonderworker obliges with a summary of Christian doctrine. But the custodian expresses doubt about the sensibility of the incarnation, so Thaumaturgus makes a further demonstration of the Christian God's power: he orders a huge boulder to pick itself up and move to a new location. With that, the custodian is converted.

This unusual story of passing notes and throwing rocks is preserved in Gregory of Nyssa's Life of Gregory Thaumaturgus, a biographical narrative account that was originally delivered as an oration in Neocaesarea (ca. 380$)^{2}$ and later preserved in writing, with some additions. ${ }^{3}$ Throughout this section of the Life, Gregory portrayed Thaumaturgus in his early ministry not only as an agent of divine power and a purveyor of true doctrines, but as a skilled pedagogue, capable of masterful fourth-century code-switching, ${ }^{4}$ varying his teaching techniques to reach diverse audiences and alternating between words and

In citations I provide numbers for the Slusser translation as well as the edition by Günter Heil in Brill's Gregorii Nysseni Opera (GNO X/1), which is the text reproduced in Maraval's 2014 Sources Chrétiennes (n. 573) edition: P. Maraval, Gregoire de Nysse. Éloge de Grégoire le Thaumaturge, Éloge de Basile (Paris, 2014). All English translations in the article are my own. A version of this paper was delivered at the 2018 Annual Meeting of the North American Patristics Society.

2 Dating follows Van Dam, who summarizes what seems to be the scholarly consensus (R. Van Dam, "Hagiography and History: The Life of Gregory Thaumaturgus," ClAnt 1 (1982): 272-308). Abramowski proposes a date post-381, after Gregory of Nyssa took on a more prominent role in church leadership (L. Abramowski, "Das Bekenntnis des Gregor Thaumaturgus bei Gregor von Nyssa und das Problem seiner Echtheit," ZKG 87 (1976): 145-166).

3 It is likely the material in sections $97-100$, Heil 55-57, was added after the oral delivery of the encomiastic bios. This hypothesis would help explain the apparent double ending of the account, in which both section 96, Heil 54 and section 100, Heil 57 employ typical closing formulae.

4 "Code-switching" is a concept mainly applied in the field of linguistics to describe the phenomenon of bilingual speakers switching between their known languages based on contextual factors: "The assumption is that the presence or absence of particular linguistic alternates directly reflects significant information about such matters as group membership, values, relative prestige power relationship, etc." (J. J. Gumperz and E. M. Hernandez, "Cognitive Aspects of Bilingual Communication," Working Papers of the Language Behavior Research Laboratory, No. 28 (Berkeley, CA, 1969): 1-19, 3). As catechist, Thaumaturgus varies his pedagogical methods based on setting and audience. 
deeds to draw people away from polytheistic religion to the Christian faith. The text depicts a priest and catechist who combines a sophisticated understanding of Christian doctrine with the ability to communicate effectively, in multiple modes, with potential converts and neophytes. He teaches in the context of a high-stakes contest or agōn, facing off against foes both spiritual and political. ${ }^{5}$ This portrait captures those features of a Christian bishop that Gregory held to be essential.

When reconstructing Gregory of Nyssa's views about bishops, their leadership, and their training in the virtues, for the most part scholars turn to a few key texts: the Life of Moses, the eulogy for Basil, and Gregory's letters to young priests. ${ }^{6}$ It is true that in these texts Gregory holds up Moses and Basil as exemplars for Christian leaders. The Life of Gregory Thaumaturgus, discussed with much less frequency, is taken to be illustrative primarily of Gregory's pride in his family's connection to the bishop responsible for "converting" the Neocaesarean region and as evidence for the spread of Origen's thought and influence in that region and family. ${ }^{7}$ But leaving the literary portrait of Thaumaturgus out of the conversation about episcopal authority is a mistake. The text's narrative presentation of the bishop's training and path to power can provide insight into how Gregory envisioned the ideal exercise of episcopal authority, especially the bishop's relationship to catechesis. Given Gregory's demonstrable interest in the design and dissemination of a Christian paideia and important fourth century debates about Christians' relationship to elite society and education under the Emperor Julian, it seems advisable to take

5 Many scholars have identified the importance of public competition in education, rhetoric, and other realms of elite male life (including early Christian leadership and debate) during the Second Sophistic. On the agonistic culture of the Second Sophistic see now relevant chapters in D. S. Richter (ed.), The Oxford Handbook of the Second Sophistic (Oxford, 2017). Specifically, on how Gregory of Nyssa's biographical writings reflect an agonistic context, see R. E. Heine, Perfection in the Virtuous Life: A Study in the Relationship Between Edification and Polemical Theology in Gregory of Nyssa's De Vita Moysis (Philadelphia, PA, 1975).

6 Michael Stuart Williams summarizes Gregory's presentation of Basil as follows: "The Praise of Basil emerges as a practical application of the appeals and arguments of the Life of Mosesand in such a way that the re-enactment of Scripture could be established as an appropriate model for modern Christian life" (M. S. Williams, Authorised Lives in Early Christian Biography: Between Eusebius and Augustine (Cambridge, 2008), 64). Among others see A. Sterk, "On Basil, Moses, and the Model Bishop: The Cappadocian Legacy of Leadership," CH 67 (1998): 227-253.

7 See, for example, Anthony Meredith's biographical study of Gregory of Nyssa, where he notes that “... Gregory Thaumaturgos is interesting and important for two reasons: (1) he brought with him the teachings and theology of his master, Origen ... (2) Gregory (the Wonderworker) was responsible for the conversion to the faith of Macrina the Elder, the paternal grandmother of Gregory of Nyssa" (A. Meredith, S. J., Gregory of Nyssa (London, 1999), 2). 
seriously the portrait of a catechist in the Life of Gregory Thaumaturgus, because it can add detail to the existing scholarly understanding of Gregory's view of the ideal bishop.

This article offers a close consideration of the narrative, focusing on how Gregory of Nyssa depicted Thaumaturgus' catechetical expertise and episcopal authority for a 4th century Neocaesarean audience. As he constructed a portrait of Thaumaturgus, Gregory also crafted a blueprint for authoritative Christian teaching in his own day. ${ }^{8}$ Like the third-century actors the text describes, Gregory of Nyssa's original intended audience could have been drawn into what he considered an ongoing contest for intellectual and cultural authority. I propose that the tension and complementarity between word and deed in Thaumaturgus' teaching may be read as a reflection of Gregory's approach to Christian paideia, especially the role of education as formation for religious leadership. Therefore the narrative can provide contemporary scholars with helpful insight into the way this fourth-century Cappadocian bishop conceived of divine condescension, constructed episcopal authority, and imagined the effective catechesis of lay Christians and their bishops.

\section{Preparation for Battle: the Bishop's Agōn}

The text's focus on teaching and training begins in the account of Thaumaturgus' own background. Gregory highlights the importance of both words and deeds in a passage that summarizes Thaumaturgus' qualifications to teach. Before he transitions from training in the enkyklios paideia and rhetoric to his priestly career, the wonderworker prays for confirmation that the divine mystery he will be teaching is true. ${ }^{9}$ In response he is sent a confidence-building

8 It is worth noting here that there are alternative literary portraits of Thaumaturgus, including a Syriac account preserved in a sixth-century manuscript and Rufinus' Historia Miraculorum. A thorough treatment of the Syriac manuscripts can be found in Michel van Esbroeck, "The Syriac Versions of the Panegyric of Gregory of Nyssa on Gregory the Wonderworker and of the Life of the Same." Journal of Eastern Christian Studies 56 (2004): 1-13. My purpose in this article is to perform a close reading of a representative episode from Gregory's bios, in the interest of demonstrating that this particular portrait should be incorporated into scholarly discussions about Gregory's views on episcopal leadership and catechesis.

9 The story of Thaumaturgus' education is found in sections 12 to 27, Heil 9-16. Throughout his narration about paideia and training in the virtues, Gregory insists that Christian teaching is superior to Greco-Roman philosophical training, citing in particular the tendency of philosophers to descend into debate and factionalism (13, Heil 9-10). Gregory claims that Thaumaturgus was educated by Origen (22, Heil 13). Scholars who discuss the likely content and timing of Thaumaturgus' education include Slusser, St. Gregory Thaumaturgus: Life and 
vision of John the Baptist and Mary, the mother of Christ, who communicate

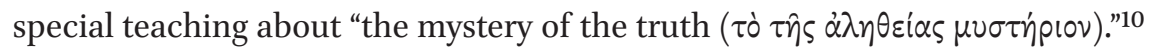
Gregory reports Thaumaturgus "at first did not have the courage (ov ... $\dot{\varepsilon} \pi \varepsilon \theta \dot{\alpha} p p \eta \sigma \varepsilon)$ for preaching the word until the truth had been revealed to him in some visible way."11 Tangible divine instruction is afforded to Thaumaturgus, who purportedly writes down the doctrinal content of his vision-a credal statement-as an "initiation" ( $\mu \nu \sigma \tau \alpha \gamma \omega \gamma$ i $\alpha$ ) that is subsequently used to catechize converts, down to Gregory's day. ${ }^{12}$ The bishop-to-be transforms an account of God's deeds into the written word, in a move that is perhaps akin to the composition of scriptural texts. ${ }^{13}$ Because the creed is transcribed for future reference, it also stands as a physical proof that future Christians may reference when they desire confirmation about the divine mystery. Gregory of Nyssa's praise for Thaumaturgus' creed almost certainly reflects his own commitment to Nicene orthodoxy; Gregory was among the staunch defenders of the homoousian position at the Council of Constantinople in 381 , which led to his appointment as promoter of that position in Pontus after the Council. ${ }^{14}$

Works, introduction; S. Mitchell, "The Life and Lives of Gregory Thaumaturgus," in Portraits of Spiritual Authority: Religious Power in Early Christianity, Byzantium and the Christian Orient, ed. J. W. Drijvers and J. W. Watt (Leiden, 1999), 99-138; and R. Van Dam, "Hagiography and History."

$10 \quad 31.3$, Heil 17.

$11 \quad 28.7-9$, Heil 16.

12 "And it is said that he rendered that divine initiation in words as soon as possible, and after that proclaimed the word in the church using it, and he left that God-given teaching to those who came after him as a sort of inheritance, by which the people in that place are initiated until today, and they are not tempted by any heretical evils" Tòv $\delta \dot{\varepsilon} \pi \alpha \rho \alpha \chi \rho \hat{\eta} \mu \alpha \tau \dot{\eta} \nu$

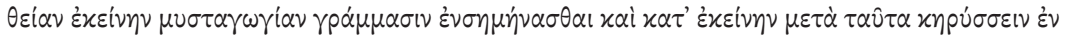

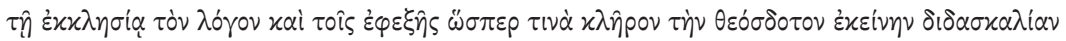

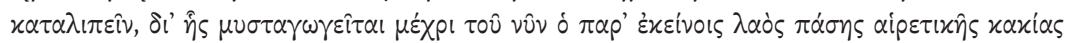
$\delta$ ¿ $\mu \varepsilon i v \alpha \varsigma \alpha \dot{\alpha} \pi \varepsilon i p \alpha \sigma \tau \circ$ (31.7-13, Heil 17).

The exact content of any such third-century inscription is not preserved, and most scholars conclude that it was not likely that a lengthy creed, like the one recorded in the bios, would have been inscribed on a church wall. A recent article by Graham Lovell seeks to situate a statement of faith by Thaumaturgus in the context of credal developments leading to Nicaea (G. Lovell, "Gregory of Neocaesarea's Theology and Statement of Faith: A Seed of the Fourth Century Theological Debates," Phronema 31 (2016): 25-57). On Lovell's reading, it was one of the "most important" goals of the Life to "promot[e] Gregory of Neocaesarea's Statement of Faith as underpinning the Nicene Creed" (28); I disagree that this is one of the primary aims Gregory of Nyssa had in mind, but it is one part of the Life.

13 On the historicity, content, and reception of the creed see Abramowski, "Das Bekenntnis des Gregor Thaumaturgus."

14 Socrates, Ecclesiastical History 5.10. 
Additionally, he appears to attribute great value to the bishop's writings ${ }^{15}$ and the power of the written word to effect change in later generations. Gregory portrays Thaumaturgus' own movement from student to teacher as a process whereby he shifts from relying on demonstrations to trusting more fully in the word and even to producing his own powerful words, and so the bishop becomes a model for the fourth-century Neocaesarean Christians who hear about his life. They, too, should apply their learning in the service of their church community.

Gregory focused on bringing the benefits of education to serve the church in his other works, and it appears he considered this a major responsibility of the elite bishop who had received training in rhetoric and philosophy. ${ }^{16}$ In the Life of Moses, he provided a figurative interpretation of the "despoiling of the Egyptians" in Exod 12:35-36, praising Moses for his demonstration that earthly learning can be used to "adorn" ( $\kappa \alpha \lambda \omega \pi i \zeta \omega)$ the church. ${ }^{17}$ Eulogizing his brother Basil, Gregory offered a synkrisis between the bishop and Moses on this point, remarking that Basil, too, turned from his "Egyptian" education to his true inheritance in the church, becoming a teacher and lawmaker like Moses. ${ }^{18}$ Moses' example appears yet again in the Life of Gregory Thaumaturgus: “... just as Scripture says about Moses, 'He was schooled in all the wisdom of the Egyptians,' so also the Great One, coming through all the schooling of the

15 Many scholars have pointed out that Gregory appears not to have been familiar with the more extensive written output of Thaumaturgus. Texts commonly attributed to him include the Address of Thanksgiving to Origen and the Canonical Epistle; English translations and a discussion about attribution may be found in Slusser, St. Gregory Thaumaturgus, especially pp. 4-8.

16 In the De vita Thaumaturgii, Gregory describes a figure named Alexander who became bishop in Comana; although Alexander presented himself as a simple and impoverished coalworker, he gave a rhetorically sophisticated speech that demonstrated his philosophical acumen. Andrea Sterk remarks about this portrayal of the educated but ascetic Alexander, "Whatever the Nyssan's reservations about pagan learning, he seemed unable to dismiss the value of education for leaders in the church, even if best abandoned in pursuit of a higher goal" (Sterk, "On Basil, Moses, and the Model Bishop," 238).

17 Gregory offers his figurative interpretation of the Exodus event in De vita Moysis II.115. In that text he simultaneously praises his brother, Basil, as a model for the appropriate and beneficial use of Greco-Roman paideia in service of the church. Perhaps the most wellknown use of the Exodus passage as a model for Christians putting Greco-Roman paideia to good use is found in Augustine's De doctrina christiana.

18 In laudem Basiliifratris 20. Greek text from Maraval, Gregoire de Nysse. Éloge de Grégoire le Thaumaturge, Éloge de Basile. 
Greeks and knowing by experience the weakness and incoherence of their doctrines, came to be a student of the gospel."19

Thaumaturgus' gradual development and his own reliance on proofs to progress toward full Christian understanding may be connected to an important theme that runs throughout fourth-century discussions of Christian learning: divine condescension. In his 2014 book, David Rylaarsdam examines

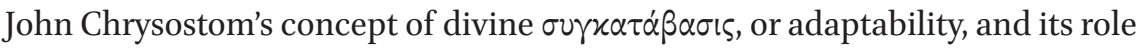
in divine pedagogy. Adaptability is a strategy drawn from classical rhetoric and includes principles like making a speech $\pi \rho \dot{\pi} \pi \circ \nu$ (appropriate or fitting) and considering the occasion for the speech (xalpós). ${ }^{20}$ Adaptability is necessary for Christian teachers because "God's nature cannot be comprehended with precision by students who are limited by their finitude, ignorance, and predilection for sin."21 Rylaarsdam points out the central role of images and exemplars in classical paideia and Christian conceptions of how God teaches. Scripture is a primary means of divine communication and pedagogy because it preserves a record of those divine acts by which "God leads people persuasively from things perceptible to the senses to the invisible realities and spiritual truth which they signify."22 For Chrysostom, Paul is the prime exemplar: "As a teacher, Paul's means of persuasion-his character, knowledge of his audience, and message - mimic and participate in divine pedagogy."23 Paul demonstrates that adaptability is a feature of divine pedagogy as well as an ideal feature of human forms of teaching, particularly catechesis. That is, the properly trained bishop can imitate God's methods of teaching. For Gregory it seems that Thaumaturgus benefited from his own experience of God's divine condescension (the furnishing of a demonstrative miracle).

In two other encomiastic bioi written in roughly the same period as the De vita Gregorii thaumaturgi, Gregory himself highlights the importance of condescension and adaptability in teaching. Gregory's De vita Moysis depicts Moses as a teacher who mediates divine content to a human audience, describing first how the biblical figure received a key component of his theological

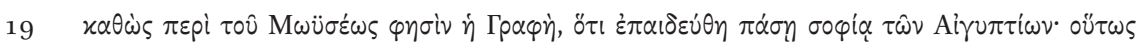

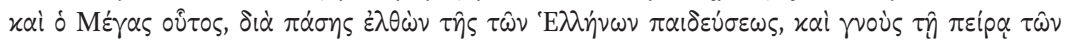

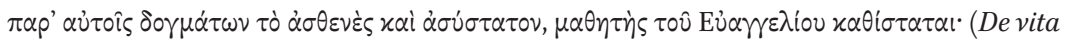
Gregorii thaumaturgi 14, Heil 10).

20 D. Rylaarsdam, John Chrysostom on Divine Pedagogy: The Coherence of his Theology and Preaching, (Oxford, 2014), 20-21.

21 Rylaarsdam, John Chrysostom on Divine Pedagogy, 54.

22 Rylaarsdam, John Chrysostom on Divine Pedagogy, 68.

23 Rylaarsdam, John Chrysostom on Divine Pedagogy, 158. 
education directly from God. Moses' own advancement in learning culminated in a mystical encounter on the mountain. The vision of the tabernacle is given in two stages, first the heavenly tabernacle, then the earthly; Moses was ready to receive the divine vision, but he is also afforded an earthly version of the revelation that he can share with those who have not yet moved beyond the need for sense-perceptible realities. ${ }^{24}$ Gregory explains this progressive revelation as an instance of divine condescension whereby mysterious things are revealed in a form that Moses' companions could comprehend. ${ }^{25}$ God's generous condescension to accommodate the limits of human understanding can, according to this text, lead to a life of the highest virtue. ${ }^{26}$

Describing his sister in the De vita sanctae Macrinae, Gregory praises Macrina's ability to transcend her own grief at the loss of her brother so that she can communicate lofty philosophical ideas about self-control and hope to her mother Emmelia. ${ }^{27}$ In a later passage, he explains how Macrina taught him about the resurrection from her deathbed..$^{28}$ Because Macrina had weathered grief and suffering and had come to understand the hope that comes from belief in eternal life, she could understand Emmelia's and Gregory's distress and accommodate her teachings to their needs. Both episodes imply that Gregory, himself a bishop, learned as a result of Macrina's adaptability. By building the vision of Mary and John, an example of divine condescension, into the way he depicts Thaumaturgus' education, Gregory of Nyssa strongly asserts a need for bishops to undergo training while also highlighting that God the adaptable divine pedagogue is a model for Christian teachers.

24 The incredibly complicated nature of the revelation and how Gregory uses it to comment on divine incomprehensibility is summed up by Ann Conway-Jones as follows: "And darkness is not the summit of the soul's journey. Within the darkness is a presence, symbolized in Life of Moses by the tabernacle not made with hands. This does not completely undercut his apophaticism, however, for within the heavenly tabernacle is the ark shielded by the wings of the cherubim: another symbol of divine incomprehensibility" (A. Conway-Jones, Gregory of Nyssa's Tabernacle Imagery in its Jewish and Christian Contexts (Oxford, 2014), 81).

25 De vita Moysis II.169.

26 Moses' vision of the tabernacle is described in great detail at De vita Moysis II.169. The ongoing importance of divine condescension even for people of exceptional virtue is confirmed in the statement that at the time of his death Moses was privileged to be called a

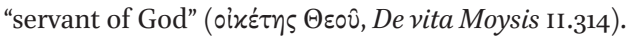

27 De vita sanctae Macrinae 9-10.

28 De vita sanctae Macrinae 17; the full text of Gregory's De anima et resurrectione purports to record the details of their dialogue. 
The bishop, as Gregory conceived of him, needed training ${ }^{29}$ because he was embroiled in a battle of cosmic proportions. Gregory uses a pair of metaphors that draw attention to the miracle worker's discipline and development, his preparation for the agōn. First Thaumaturgus is described as being "like an athlete ( $\kappa \alpha \theta \dot{\alpha} \pi \varepsilon \rho \tau \iota \varsigma \dot{\alpha} \theta \lambda \eta \tau \eta \dot{\varsigma})$ who, since he has enough experience from competition and strength from training, strips confidently for the race and prepares for combat against his competitors." 30 Imbued with both strength and confidence, Thaumaturgus the athlete is ready to proceed to a pagan temple and square off against demons; indeed, as we will see in a moment, he "prevails $(\kappa \alpha \tau \eta \gamma \omega \nu i \sigma \alpha \tau 0)$, through faith, against every power of the Adversary." The athletic metaphor, in early Christian texts from Pauline epistles forward, is frequently used to highlight personal discipline or askēsis, and in this case it marks Thaumaturgus as one who prepares appropriately. ${ }^{31}$

The second metaphor Gregory employs, an image of armed combat, emphasizes Thaumaturgus' role in a larger struggle that extends beyond his individual tasks and preparation. Equipped for fighting, he is "like some noble soldier because of whom the upper hand is changed when he joins the battle-line"

29 Admittedly, Gregory appears to describe another form of authorization for bishops later on in the bios (62-72, Heil 36-41). Thaumaturgus recognizes that the unassuming Alexander in Comana is the most virtuous and suitable candidate for the bishopric, and he insists that this man be anointed despite his apparent lack of education or public stature. However, it is eventually revealed that the Alexander who disguised himself as a charcoal maker was in fact in possession of a sophisticated philosophical mind, a fact he demonstrates by giving a stirring speech; the style is rough, but the content is worthy. On my reading the passage is not so much a rejection of formal education as it is a demonstration of Thaumaturgus' ability to discern true quality despite external appearances, and so it should not be taken as an assertion that bishops need not be educated.

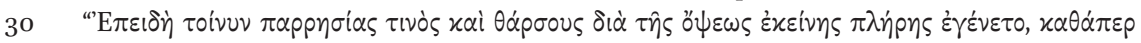

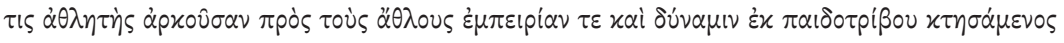

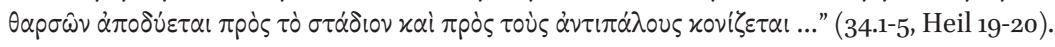

31 Paul describes himself and others as athletes at 1 Cor 9:24-27, though the fullest development of the metaphor comes in the Pastoral Epistles (2 Tim 2:5 and 4:7). Paul refers

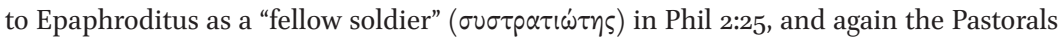
imagine soldiers in the faith (2 Tim 2:3-4). The "armor of God" ( $\pi \alpha v 0 \pi \lambda i \alpha)$ metaphor, implying believers are soldiers entering a battle, appears in 1 Thess 5:8 and the Deutero-Pauline Eph 6:10-17. James R. Harrison, in a 2008 essay, situates Pauline use of athletic metaphors in the wider context of visual culture. He draws on images from ceramics, statuary, coins, etc. to demonstrate that Paul's employment and critique of athletic imagery was responding not just to literary but also visual portrayals of athletic excellence (J. R. Harrison, "Paul and the Athletic Ideal in Antiquity: A Case Study in Wrestling with Word and Image," Paul's World, ed. S. E. Porter, Pauline Studies 4 (Leiden, 2008), 81-109). A more general introduction to the use of the athletic metaphor in Paul may be found in V. C. Pfitzner, Paul and the Agon Motif: Traditional Athletic Imagery in the Pauline Literature (Leiden, 1967). 


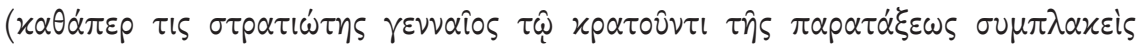

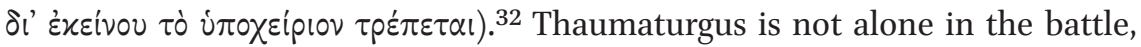
but he plays a decisive role. His military-style leadership and strategic skill, displayed early in his ecclesial career, later comes to fruition in further trials against human enemies, such as imperial representatives who seek to persecute the wonderworker's congregation. ${ }^{33}$ It is significant that Thaumaturgus is specially trained and also able to lead others in a cooperative enterprise.

Through the account of Thaumaturgus' vision and the use of carefully selected metaphors, Gregory depicts an idealized teacher who relies on assistance from God and then puts himself in the service of others, to suggest that Christian catechesis cannot be fully successful without a teacher who can empathize with and adapt to those he teaches as they, too, enter the field of combat. Thaumaturgus' ability to code-switch for multiple audiences comes from his own varied educational experiences as he progressed from novice to initiate to a person intimately familiar with Christian doctrine.

\section{Passing Notes to Demons: the Bishop's Schoolroom}

Gregory presents the contest between Thaumaturgus and the demons as a competition for the belief of a temple custodian and as a story about establishing Christian community. For both achievements, Thaumaturgus must rely on a careful toggling between word and deed in order to convince or persuade. As Gregory tells the story, Thaumaturgus is allied with the true God, who is unquestionably superior to the demonic forces in the local temple. After he has spent the night in the temple, the demons find themselves barred

$32 \quad 34.21-23$, Heil 20.

33 Later in the text, Gregory again praises Thaumaturgus' leadership using military terminology, likening him to a general and the Christians in his community to the soldiers under his authority. When the Roman emperor (either Decius or Valerian) issued an edict that led to the localized persecution of Christians, Thaumaturgus apparently assessed the situation like a military commander. Gregory writes that he "became a signifier for the church to pull back a little from the fearful attack, thinking it better that they should save their lives by flight than that, by standing in the battle line of the contest, they should become desert-

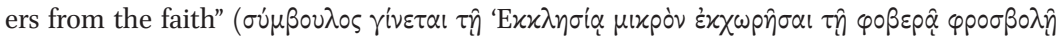

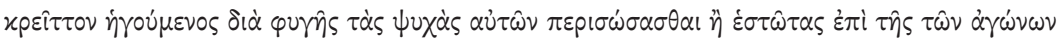
$\pi \alpha \rho \alpha \tau \dot{\alpha} \xi \varepsilon \omega \varsigma \lambda \varepsilon เ \pi 0 \tau \dot{\alpha} x \alpha \tau \alpha \varsigma \gamma \varepsilon v \varepsilon \dot{\sigma} \theta \alpha \iota \tau \hat{\jmath} \varsigma \pi i \sigma \tau \varepsilon \omega \varsigma, 84.3-7$, Heil 47). Even the enemies who seek to attack Thaumaturgus and his congregation recognize the central leadership role of the wonderworking bishop, and the Roman authorities determined that "by capturing him like a general they might shatter the whole battle line of the faith" ( $\tau$ ò $\delta$ ' ह่ $x \varepsilon$ ivou $x \alpha \theta \dot{\alpha} \pi \varepsilon \rho \sigma \tau p \alpha-$

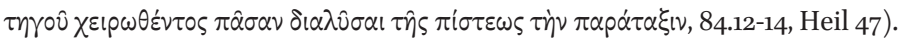




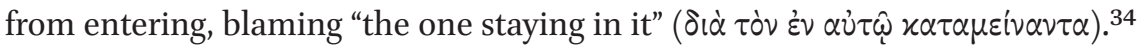
Demons continue to communicate with the custodian who had been accustomed to serving them, disclosing that they are unable to enter the space because of Thaumaturgus' presence and his prayers. Gregory does not narrate the initial contact between Thaumaturgus and the demons, emphasizing instead Thaumaturgus' use of both words and deeds to engage with the human custodian once the custodian discovers his livelihood is threatened. The custodian's initial reaction is anger. In part, this appears to be a response to his own impotence, for despite the custodian's efforts "by certain purifications and sacrifices" ( $x \alpha \theta \alpha \rho \sigma i o \iota s \tau i \sigma i$ xai $\theta v \sigma i \alpha ı)$ ) to entice the demons to return, they cannot enter the temple while Thaumaturgus is present. ${ }^{35} \mathrm{In}$ his personal competition against this interloper, the custodian comes up short.

Yet more than individual power is at stake, and the custodian's response firmly situates the episode in a wider context of conflicting belief systems and competing sources of authority. Just as earlier Gregory presented Thaumaturgus as one soldier in the cosmic battle line, so here the custodian conceptualizes Thaumaturgus as one representative of a larger, threatening force. In particular, the custodian objects to someone who is "a Christian and

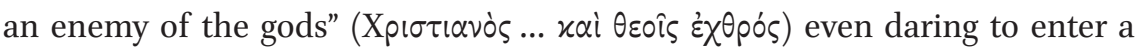
temple. ${ }^{36}$ Positioning himself in an opposed battle line, the custodian threatens "to impeach [Thaumaturgus] to the authorities, to use force against him, to inform the emperor of his recklessness." ${ }^{37}$ In the third century, this kind of accusation of antisocial behavior leveraged against Christians carried a real danger of legal penalties, or even capital punishment. We know from later in the text that Thaumaturgus himself had to steward the Christians in Neocaesarea through a period of persecution, probably under Decius. ${ }^{38}$ Gregory defends Thaumaturgus's decisions at that point to flee from the city to avoid danger, ${ }^{39}$ but in this early episode, Gregory praises Thaumaturgus for standing up to his

$34 \quad 34 \cdot 5-6$, Heil 21.

3536.6 , Heil 21.

$36 \quad 36.14$, Heil 21.

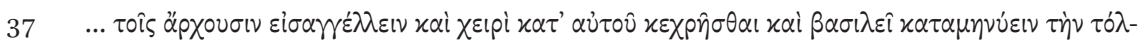
$\mu \alpha \nu$ (36.12-13, Heil 21).

38 On Thaumaturgus and the persecution under Decius, see pages 273-274 of Van Dam, "Hagiography and History."

39 In the face of a persecution that seems to drive Christians to betray each other or undergo cruel punishments, Thaumaturgus adjusts his pastoral style to accommodate "the weak-

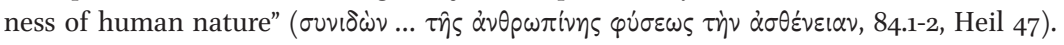
Instead of encouraging Christians to "stand in the battle line of the contest" ( $\dot{\sigma \sigma \omega \tau \tau \alpha \varsigma} \dot{\varepsilon} \pi \dot{\imath}$ $\tau \hat{\eta} \varsigma \tau \hat{\omega} \nu \dot{\alpha} \gamma(\omega) \nu \omega \nu \pi \alpha \rho \alpha \gamma \alpha \dot{\xi} \xi \omega \varsigma)$ where they might be tempted to "become deserters from the

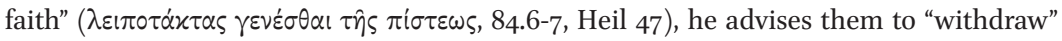


interlocutor. The contest for authority takes place, in part, through engaging with the right words.

The threat of being denounced to the emperor might have resonated especially strongly with a fourth-century audience who had lived through the reign of the emperor Julian, in $361-363 \mathrm{CE}$. The Cappadocians in particular were deeply invested in combating "the apostate" and his view of Christianity as intellectually and philosophically inferior. ${ }^{40}$ Julian's edict against Christian teachers forbade them from teaching texts about gods in whom they did not believe. Ostensibly focused on a religious issue, it had the effect of barring Christian teachers and their students from the world of elite male culture, which was profoundly shaped by and instantiated in the texts of classical paideia. ${ }^{41}$ As Raffaella Cribiore points out, an elite education held the promise of political and legal careers, motivating many to pursue the highest levels of rhetorical study in hopes of social and economic advancement. ${ }^{42}$ Partly in response to this edict and its effects, the Cappadocians sought to develop a distinctive, Christian paideia that nevertheless recognized the value of nonChristian texts and models. For example, Gregory of Nyssa portrayed his sister Macrina as the beneficiary of a Christian education but simultaneously as a figure embedded in the world of classical philosophy. He praised his mother Emmelia for outlining a course of Scriptural readings for the young Macrina in the Vita sanctae Macrinae, ${ }^{43}$ then depicted Macrina in the role of Socrates in

( $\dot{\chi} \chi \omega p \hat{\sigma} \sigma \alpha \iota, 84.4$, Heil 47) from the enemy's onslaught. He himself models caution through flight, which Gregory describes as a compassionate move.

40 For the broad contours of this debate, see the excellent treatment of Julian and Gregory Nazianzus in S. Elm, Sons of Hellenism, Fathers of the Church: Emperor Julian, Gregory of Nazianzus, and the Vision of Rome (Berkeley, CA, 2012).

41 On the role of paideia in shaping elite male culture in the empire, see especially the following: M. W. Gleason, Making Men: Sophists \& Self-Presentation in Ancient Rome (Princeton, NJ, 1995); R. A. Kaster, Guardians of Language: The Grammarian and Society in Late Antiquity (Berkeley, CA, 1988).

42 R. Cribiore, Gymnastics of the Mind: Greek Education in Hellenistic and Roman Egypt (Princeton, NJ, 2001), 3.

43 The course of Christian readings set by Emmelia begins with Proverbs then proceeds through Ecclesiastes to the Song of Songs (VSM 3). Throughout the Vita Gregory notes that Macrina and her household devote themselves to the singing of Psalms, a key component of their ongoing learning (see vsm 11). David Martinez notes, based on extant papyrus copies, that the Psalms were highly popular among early Christians and perhaps held a status similar to the Homeric material for education (D. Martinez, "The Papyri and Early Christianity," in The Oxford Handbook of Papyrology, ed. R. S. Bagnall (Oxford, 2011), $590-622$ at 593). 
the dialogue De anima et resurrectione. ${ }^{44}$ Basil, too, addressed the question of how a Christian ought to appropriately engage with classical texts in his treatise on the education of young men, Ad adulescentes. ${ }^{45}$ As Ellen Muehlberger points out in a 2012 article, Basil's emphasis on Christians training themselves to be discerning readers places the onus on interpreters rather than on the texts themselves, "for if Christian readers can trust themselves to recognize 'virtue,' they should read widely, making use of all the literature available to them." ${ }^{46}$ The focus on the proper interpretation and use of existing texts led to the creation of a new, Christian identity that was not fully divorced from earlier models of education. ${ }^{47}$ Vasiliki Limberis argues that Gregory of Nazianzus embraced an expansive cultural heritage: "In claiming Greek learning for the Christians, he augments the traditional Christian identity in an innovative way. He builds his concept of Christian religious identity on the pre-Constantinian pagan paideia."48 As all three Cappadocians attempted to demonstrate, the bishop's cosmic battle also had a concrete, cultural dimension, one that was instantiated in the form of a syllabus or reading list. The deeds that accompany a Christian life are contingent upon training with and from the proper words.

The next events in the Vita are intriguing, as word and deed become joined together in the form of an episcopal text: Thaumaturgus writes a command on a piece of paper, and the demons obey. His wording is terse and direct:

44 For a discussion of Macrina portrayed as philosopher, see especially E. Muehlberger, "Salvage: Macrina and the Christian Project of Cultural Reclamation," CH 81 (2012): 273-297.

45 Ernest L. Fortin points out that Basil provides his own, seemingly idiosyncratic interpretations of key passages from the Homeric texts as a way of priming his young male readers to encounter these texts with a Christian lens already in place. Fortin writes, "If there is anything to be learned from Basil's address, it is that the co-optation of the pagan classics as a kind of praeparatio evangelica or propaedeutic to the faith entailed not so much the appropriation of the old values as their transmutation in accordance with the demands of the Gospel" (E. L. Fortin, "Hellenism and Christianity in Basil the Great's address Ad adulescentes," Neoplatonism and early Christian thought: essays in honour of A. H. Armstrong, ed. H. J. Blumenthal and R. A. Markus (London, 1981), 189-203, 199).

46 Muehlberger, "Salvage," 291.

47 Catherine Chin expresses this idea clearly: "Christianization is not the same as an accumulation of individual conversions, nor is it the same as the demise of paganism; it is the addition of a new narrative of identity to the field of narratives being produced in late antiquity" (C. M. Chin, Grammar and Christianity in the Late Roman World (Philadelphia, PA, 2008), 171).

48 V. Limberis, "Religion' as the Cipher for Identity: The Cases of Emperor Julian, Libanius, and Gregory Nazianzus," HTR 93 (2000): 373-400, 399. 


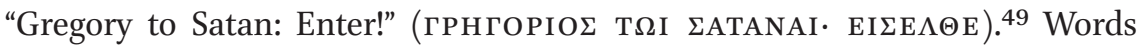
have power. However, the focus is not on just any words, but on the written word. Paired with Gregory's discussion of the "initiation" statement or creed that Thaumaturgus left his Neocaesarean congregation, this passage and its attention to the written word suggest that Gregory places a high premium on the textual output of bishops, even when that output consists of four words. Like Thaumaturgus' creed, the written command functions as a tangible record of the wonderworking bishop's faith, which may inspire Christians of later generations. Derek Krueger explains that the very act of early Christian literary production (from the New Testament texts to hagiographical writing) was considered a devotional, spiritual practice, a "technique for the representation of holiness,"50 and Morwenna Ludlow highlights the importance of text for Gregory in particular, pointing out that "in the many presentations of teachers and pupils across his ouevre, Gregory's construction of the role of teachers and pupils is intimately connected with texts, both the texts which teachers read and use in the classroom, and the texts which are the result of their teaching." ${ }^{51}$ By prioritizing the preservation of a bishop's written record, Gregory may be subtly advertising the importance of his own work about Thaumaturgus, reminding the fourth-century audience that the Christian literary product they hear or read has inherent power to guide and inspire.

That Thaumaturgus uses his own name to banish the demons seems significant. Based on biblical precedent, we might expect to read about commanding spirits in the name of Jesus, with the glory redounding to Christ and God, but these events appear to bolster the specific power of Thaumaturgus. ${ }^{52}$ The demons resume their place, which the custodian con-

4938.15 , Heil 22.

50 D. Krueger, Writing and Holiness: The Practice of Authorship in the Early Christian East (Philadelphia, PA, 2004), 6.

$5^{1} \quad$ M. Ludlow, "Texts, Teachers and Pupils in the Writings of Gregory of Nyssa," in Literature and Society in the Fourth Century AD: Performing Paideia, Constructing the Present, Presenting the Self, ed. L. Van Hoof and P. Van Nuffelen (Leiden, 2014), 83-102 at 85.

$5^{2}$ The authorized use of Jesus' name for exorcism is the subject of some debate in the gospel tradition. The efficacy of Jesus' name for carrying out an exorcism is upheld in Mt 7:22, where Jesus predicts that people will claim they have been able to cast out demons in his name even though he would identify them as evildoers. At Mk 9:38-41 (parallel in Lk 9:49-50), Jesus has to combat the disciples' concern that people who are not part of their group are nevertheless able to cast out demons in Jesus' name. His well-known reply ("whoever is not against you is for you") appears to reinforce the idea that the name itself is efficacious, regardless of any other form of allegiance declared or displayed. A more difficult passage appears in Acts 19:13-17, where Jewish exorcists who are sons of the high priest Sceva try to cast out demons in the name of "the Jesus whom Paul proclaims" but 
firms by performing some of his usual cultic actions, to the usual effect. Impressed, he asks Thaumaturgus to tell him about the God who is able to command demons, and the wonderworker assents. Gregory notes that, predictably, the custodian found it difficult to believe that the incarnation could have taken place, on the grounds that such a powerful God would never take on human flesh. ${ }^{53}$ Thaumaturgus' response to this objection is important: he explains that "the trustworthiness of this concept was not strengthened by arguments, but has its trustworthiness because of the wonderfulness of the

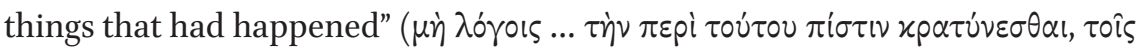

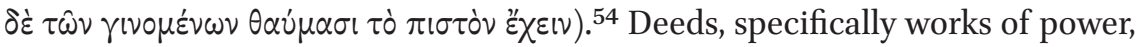
confirm the truth of difficult teachings. The exact referent is not clear-does he mean Jesus' exorcisms and healings, or does he intend to include all divine wonders since the time of creation? The rest of the episode may shed some light on this question.

The second stage of Thaumaturgus' miracleworking provides a wonder that can further convince the recalcitrant custodian. The custodian himself requests that Thaumaturgus move a large stone from one location to another, and "not at all taken aback, that great one immediately ordered the rock as if it were a living thing to be translated to the place which the temple custodian

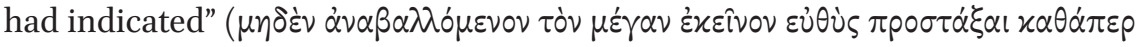

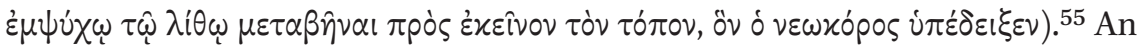
episode from the synoptic gospels may resonate for readers of this passage. Just after Jesus casts out a demon, he has a brief discussion with the disciples, who had been unable to cast out the demon themselves. Jesus attributes their failure to a limited faith (literally "little faith," o $\lambda ı \gamma o \pi ı \tau \tau^{\prime} \alpha$ ) and tells them that "if you have faith the size of a mustard seed, you will say to this mountain, 'Move from here to there,' and it will move." ${ }^{56}$ Thaumaturgus' stone could be standing in for the disciples' movable mountain. Or perhaps this stone is like that which was rolled away from the tomb (Mk 16:4; Mt 28:2), and Thaumaturgus

are unable to do so because they themselves are unknown to the demons, who ultimately attack them.

53 As Maraval notes in his edition of the text, "C'est l'objection classique des païens durant les premiers siècles, à laquelle répondent de nombreuses pages sur la convenance de l'Incarnation, chez Origène, Eusèbe de Césarée, Athanase et bien d'autres" (Gregoire de Nysse. Éloge de Grégoire le Thaumaturge, 149 n.1).

$54 \quad 39.10-12$, Heil 22.

55 40.7-9, Heil 22-23, my emphasis.

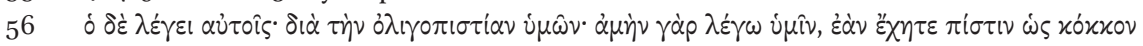

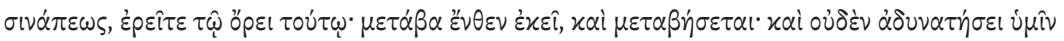
(Matthew 17:20; the full pericope runs from Mt 17:14-20, with parallels in Mk 9:14-29 and Lk 9:37-42). 
demonstrates the incarnation and resurrection were possible by recreating a scene from the resurrection. ${ }^{57}$ Even with the likely gospel referents,

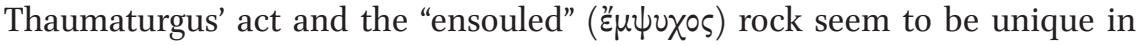
early Christian miracle accounts. The closest comparandum is to be found in the Vita Abercii, when the Christian Abercius commands a demon to relocate a massive stone altar from Rome to Abercius' distant hometown. ${ }^{58}$ However, the stone here is "ensouled," and Thaumaturgus needs no intermediary in his display of command over the natural world. In fact, although there are demons present and he has already shown he can give them orders, he bypasses them entirely and performs the labor without their assistance. Gregory's focus on Thaumaturgus' direct control of spiritual power serves mainly to heighten the reputation of this specific bishop.

Gregory ventures a rather daring synkrisis to conclude the episode, placing Thaumaturgus in the position of disciple but also linking his power to the creative, animating power of God:

[the custodian] was converted to the true God, inferring from what his servant had done how inexpressible is the power of the Lord. For if the power of the servant was such as by a word to move the immovable, and by a command to prevail against things without sensation, and to direct things without souls, how much greater a scope of power should we understand the ruler of all to have, whose will became the matter and structure and power of the world and of everything in it and of those things which are above it? ${ }^{59}$

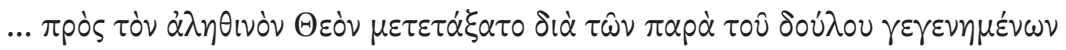

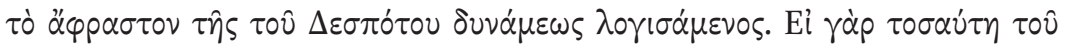

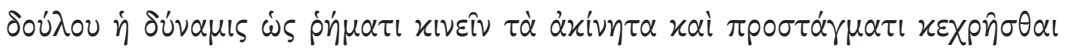

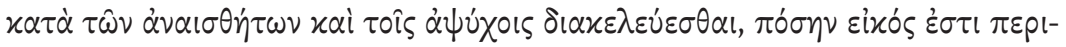

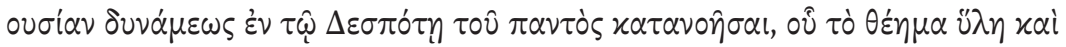

57 The women approaching the tomb in Mark's gospel express their concern that moving the stone to access and anoint Jesus' body will be difficult because of the size and weight of the stone (Mk 16:3-4).

58 Treatment of the Abercius narrative and the complex story of the associated artifact may be found in M. M. Mitchell, "Looking for Abercius: Reimagining Contexts of Interpretation of the "Earliest Christian Inscription," in Commemorating the Dead: Texts and Artifacts in Context. Studies of Roman, Jewish and Christian Burials, ed. L. Brink and D. A. Green (Berlin, 2008), 303-335.

59 41.8-30, Heil 23-24. 


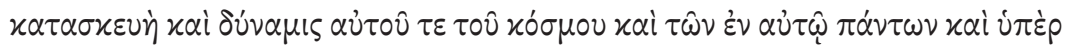

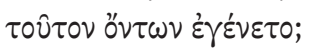

Gregory makes it abundantly clear that the stone itself is only animated because of the power of Thaumaturgus, who is himself displaying only the power of a servant, a fraction of God's abilities. Reasoning from the lesser to the greater, a reader ought to marvel at the absolutely superior power of the creator God. ${ }^{60}$ The stone itself is not living, a subtle jab against the idolatry the custodian had been engaged in before Thaumaturgus' arrival. Gregory the narrator comments poetically, "A stone causes those who served stones to forsake stones" ( $\Lambda$ i

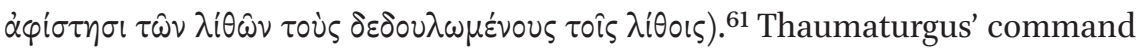
over material objects, perhaps including his use of the written word, serves as a tangible demonstration of the effectiveness of the incarnation: deeds again confirm words. Significantly, Thaumaturgus illustrates that divine power is not confined to the life of Jesus or the pages of Scripture but can be encountered in his and the custodian's day ${ }^{62}$ Part of his display of authority includes his ability to render visible and tangible the divine power that is normally invisible, mainly encountered only in the words of texts or homilies.

Thaumaturgus' authority and the adaptability he demonstrates by rendering the plausibility of Christian teachings visible for a reluctant audience leads to the formation of a new community. The custodian gives up everything that had previously been his in order to follow Thaumaturgus and "to take part with

6o Gregory applies the general rhetorical principle of reasoning from the lesser to the greater in support of some thesis, in this case a theoretical (vs. practical) thesis about the power of God; for more information on the efficacy of "lesser to greater" in argumentation, see the Progymnasmata of Aelius Theon (1st century CE), p. 122 in L. Spengel, ed. Rhetores Graeci, vol. 2 (Leipzig, 1854-56). An English translation is available in G. A. Kennedy, Progymnasmata: Greek Textbooks of Prose Composition and Rhetoric (Atlanta, GA, 2003); see pp. 56-57.

6141.8 , Heil 23.

62 Michael Stuart Williams explores the idea that early Christian biographers often elided the distinction between their present and the biblical past in order to demonstrate that history partakes in scriptural traditions (Williams, Authorised Lives in Early Christian Biography, 16). He holds up Gregory as a prime example of a biographer who takes this approach in his praise of Basil, specifically by drawing frequent comparisons between Basil and Moses: "In relating the life of his brother, then, Gregory adopted the example of Moses as a scriptural model-another example of a Christian author presenting his world in terms of the re-enactment of Scripture. Moreover, he took the complementary step of also applying this parallel in his efforts to describe and explain the world of the Bible. Thus his Life of Moses, while in many ways an allegorizing account, shows the influence of typology in an unexpected way by portraying Moses both as a man and as a Christian leader in terms borrowed from the career of Basil" (19). 


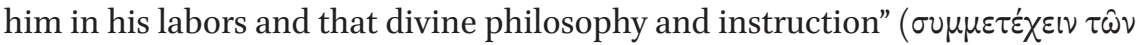

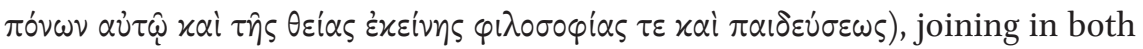
the intellectual pursuits and their material consequences. ${ }^{63}$ Thaumaturgus is able to inspire the kind of devotion that defines the ideal disciple in the synoptic gospels (Mk 10:29-30 and parallels), further proof that powerful deeds are not relegated to the biblical past. ${ }^{64}$ Perhaps most importantly, the episode depicts an ideal instance of episcopal pedagogy: an appropriately trained bishop explains theological principles and illustrates their practical effects, adapting his teaching style to the needs of a particular audience, which leads to a positive outcome and the growth of the church.

\section{The Bishop's Seat: Exemplary Authority}

Thus far the Life outlines a catechetical program that relies equally on doctrine and demonstration, words and deeds. Both forms of teaching are geared towards the needs of an individual (whether bishop-in-training or new convert). But does the same balanced approach apply once the bishop is dealing with a more diverse audience like an entire congregation? By examining one final episode - the description of Thaumaturgus' early days in Neocaesarea-we may discover how Gregory imagined the relative power of words and deeds for establishing episcopal authority in community.

Thaumaturgus enters the city, and crowds of people who have heard the news of his accomplishments come out to see him. Their admiration stems from the fact that he, "though a human being, has authority ( $\left.\xi^{\prime} \xi o v \sigma^{\prime} \alpha\right)$ like some king over those whom they consider gods, seemingly able to order the demons to and fro wherever he wants, like wartime captives ..." ${ }^{65}$ They appear to have heard about his mastery over the temple demons. The people are also impressed by the obvious devotion of the custodian who is now Thaumaturgus' companion. ${ }^{66}$ Instead of allowing himself to be distracted by the opulence of the city or dignitaries in the crowd, Thaumaturgus ignores them completely and proceeds "as he would through a desert," which only serves to impress

\footnotetext{
63 40.13-15, Heil 23.

64 Mk 10:29-30; Mt 19:28-29.

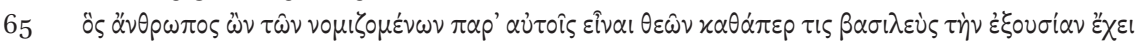

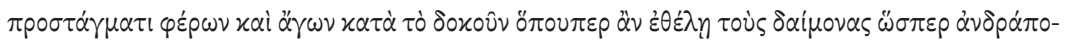
$\delta \alpha \ldots$ 42.10-14, Heil 24-25.

66 Gregory specifically remarks that the custodian has given up his former way of life, with its possessions and honor $\left.(\tau \mu \mu)^{\prime}\right)$, in favor of "the way of life with him" ( $\dot{\eta} \mu \varepsilon \tau$ ' $\alpha \dot{v} \tau 0 \hat{\delta} \delta \alpha \gamma \omega-$ Yं; 42.15-17, Heil 25).
} 
them further. ${ }^{67}$ Gregory describes the wonderworker's lack of concern for material goods and wealth as a display of virtue; as Gregory puts it, "virtue and faith were heritage and home and wealth to him."68

Immediately, Thaumaturgus supplements his display of otherworldly focus with an explanatory speech. He rejects the importance of material houses, since they can be used to conceal dishonorable deeds, and there is no need for the virtuous to hide. Besides, he says, God should be a sufficient shelter: "Or are you cramped by the vault of heaven and seek a lodging other than this?"69 Of course, Thaumaturgus does eventually accept an invitation to stay at the home of a wealthy host! Gregory frames this move as proof of Thaumaturgus' respect for and adaptation to the community's view of things. Nevertheless, it seems significant that Thaumaturgus initially establishes his superiority through deeds and then words, visibly staking out an exalted moral position from which he can provide authoritative teachings.

Thaumaturgus gains the moral high ground by modeling a gospel-inspired detachment from worldly things. ${ }^{70}$ In so doing, he simultaneously adopts a stance common to many bishops in his time and demonstrates his possession of the catechetical adaptability that was of special importance to Gregory. Gregory was not alone in lionizing asceticism and its value for bishops. In her 2005 book on Holy Bishops in Late Antiquity, Claudia Rapp notes that "for the discharge of his pastoral obligations, the bishop needed to set an example of moral and virtuous conduct to his congregation." ${ }^{71}$ Rapp identifies this kind of behavior as a source of ascetic authority. ${ }^{72}$ Such ascetic authority appears to have been not just beneficial but indispensible to Gregory's conception of

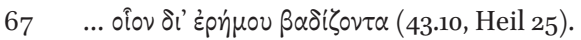

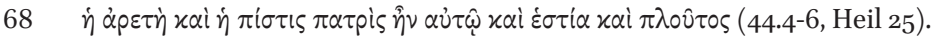

69 The speech, replete with rhetorical questions and frequent dichotomies (heaven versus earth, wickedness versus virtue, concealment versus openness), appears in 44.9-23, Heil

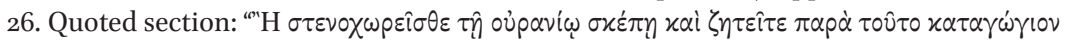

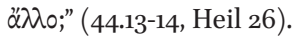

70 Gospel passages recommending detachment from worldly goods are generally directed toward the disciples and include specific instructions about giving up one's possessions. Examples include Lk 12:33, which follows the parable of the rich man in Lk 12:13-21 and a lesson about trusting in God's providence in Lk 12:22-31. Acts 4:32-37 describes the early Christ-believing community sharing their goods and income in common, an ideal situation reinforced by the story of punishment for withholding one's goods in 5:1-11.

71 C. Rapp, Holy Bishops in Late Antiquity: The Nature of Christian Leadership in an Age of Transition (Berkeley, CA, 2005), 24.

72 She lays out a threefold model of episcopal authority (spiritual, ascetic, and pragmatic authority). For descriptions of each type and the relationship between the three types, see especially Chapter 1, "The Nature of Leadership in Late Antiquity," Holy Bishops in Late Antiquity, 3-22. 
religious leadership. It is clear from Gregory's bios about Macrina that he deeply admired her asceticism and took pains to document its profound effect on the women in her household. ${ }^{73}$ It was her asceticism that rendered her way of life an approximation of the angelic life on earth. ${ }^{74}$ Gregory's immediate family members-Macrina, Emmelia, Naucratius, and Basil—all pursued a form of monastic or ascetic life. ${ }^{75}$ Basil's Asketikon provides explicit instructions for life in Christian community and explores the role of community in training more virtuous people. In a 2011 article, Joseph Ballan explores the idea that Basil's rule depicts asceticism as a craft, a skill that requires practice and must be tested and put to use. ${ }^{76}$ Because asceticism is a skill that may be developed, it is theoretically a possibility for all Christians, not just elites or monastics, but it is nearly a requirement for bishops. Asceticism is linked to exemplarity in part because it was a way for bishops to align themselves with or even recreate the lives of biblical figures like Moses and Elijah.

The ascetic ethos of the bishop therefore played a role in extending God's pedagogical condescension to the Christian community. Rylaarsdam points out that the exemplary priest engages in ethical behavior in part to reject intellectual elitism that could be an obstacle to effective teaching: "In addition to teaching Christian philosophy through an authoritative text in the school of the church, a priest teaches through the power and example of his own character." 77 Education has to entail not just philosophical, rhetorical, and

73 Hans Boersma connects the praise of Macrina's asceticism to Gregory's larger anagogical project and understanding of human beings as constantly pursuing virtue: "Gregory regards physical virginity as an initial embodied manifestation of the defeat of death and thus as the highest possible stage of ascent" (H. Boersma, Embodiment and Virtue in Gregory of Nyssa: An Anagogical Approach (Oxford, 2013), 117).

74 Vita Sanctae Macrinae 11.

75 For a description of the domestic ascetic community of Macrina and Emmelia, see the Vita Sanctae Macrinae 6 and 11. Nathan D. Howard points out that part of Gregory's motivation for writing the bios about Macrina may have been to capitalize on descriptions of her ascetic discipline to bolster the reputation of the entire family (N. D. Howard, "Familial Askêsis in the Vita Macrinae," StPatr 47 (2010): 33-38). The story of Naucratius' ascetic retreat, life of service, and untimely death may also be found in that text, at vSM 7-8. Both Gregory of Nyssa and Gregory of Nazianzus highlight Basil's commitment to ascetic community in their respective eulogies. For a comparison of how the two Gregories eulogize their fellow bishop, see A. Meredith, "Gregory of Nazianzus and Gregory of Nyssa on Basil," StPatr 32 (1997): 163-169.

76 J. Ballan, "Basil of Caesarea on the Ascetic Craft: The Invention of Ascetic Community and the Spiritualization of Work in the Asketikon," HeyJ $5^{2}$ (2011): 559-568, 562.

Rylaarsdam, John Chrysostom on Divine Pedagogy, 200. 
theological knowledge, but also the catechist's individual character. Christians presented this ethical excellence as a foil for the alleged moral turpitude of their pagan counterparts, the philosophers and sophists. There is some irony in the fact that philosophers leveled the accusation of poor morals against each other almost as a matter of course during the Second Sophistic period, and so application of the polemic by Cappadocians and others quite effectively illustrates Christianity's deep embeddedness in the elite intellectual discourse of their time. Nevertheless, the portrait of Thaumaturgus here aligns with contemporaneous Christian portraits of the self-denying bishop as model of virtue and magnetic figure.

Thaumaturgus' demonstrated virtue draws a crowd, and Gregory describes how his ability to be adaptable while balancing words and deeds founds a community of faith. Thaumaturgus "was in their midst, by the power of the Spirit sharing fittingly according to the needs of each: proclaiming, discerning, directing, teaching, healing." ${ }^{18}$ Ultimately, the community is inspired to construct a church that manages to survive an otherwise devastating earthquake, serving as a lasting, material testament to Thaumaturgus' teaching and the effectiveness of his catechesis. In the ongoing cosmic and cultural agōn, there could be no more concrete sign of Thaumaturgus' success than the Neocaesarean church building. As Vasiliki Limberis points out in an article on Julian, Libanius, and Gregory Nazianzus, a Greco-Roman temple could function as "an incarnation of civilization's cultural heritage."79 Over the course of this episode, Thaumaturgus has rendered the pagan sacred space void and established a Christian church filled with devotees, literally and symbolically reconfiguring the cultural landscape. For Gregory the biographer, Thaumaturgus deserves praise for having translated abstract Christian teaching, through his own ethical modeling, into a concrete sign of Christian power and unity. Gregory notes that the worship space should be interpreted as a testament to the excellent work of Thaumaturgus, who adapted this teaching appropriately to a number of local constituencies: "By distributing to women what was useful, to children what was suitable, to fathers what was proper, and by 'becoming all things to all' (1 Cor 9:22), he built up for himself such a crowd of people (with the cooperation of the Spirit), that they wanted to begin construction for

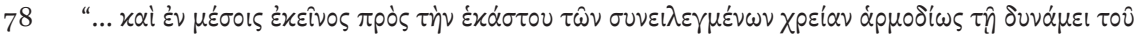

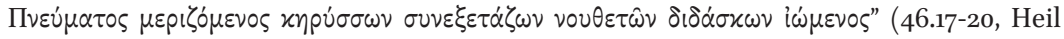
26-27). 
a temple, all of them rendering service towards this goal with their goods and their bodies." 80

Comparing the sequence of events in Neocaesarea to what happened with the custodian and the boulder, we can detect the same catechetical pattern: Thaumaturgus offers a careful sequence of words and deeds to create new converts, who join their way of life to his, adopt a properly virtuous attitude to material goods, and constitute a new community with shared goals. By using words to demonstrate his familiarity with divine truth and deeds to demonstrate his access to divine power, Thaumaturgus effectively cements his authority as a founder and leader in Neocaesarea.

It is possible to read this episode as prioritizing words over deeds. On such a reading, verbal teaching is more important than the works of power, inasmuch as those works bolster or secure a faith that is primarily dependent upon a correct understanding of doctrine. Indeed, many scholars have pointed out that Gregory's writings appear to outline for Christians a steady progression from relying on sense perceptible realities to engaging with the divine noetically, beyond sense-perceptions, ${ }^{81}$ depending instead on analogy while remaining conscious of human limits 82 and the limits of

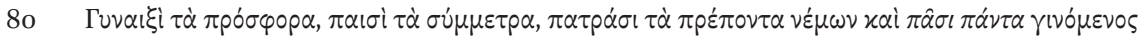

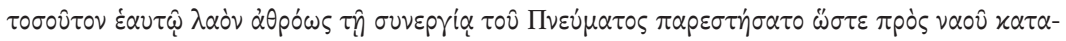

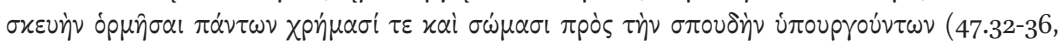

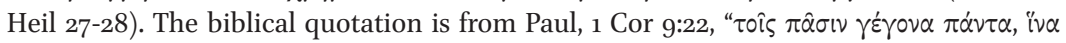
$\pi \dot{\alpha} \nu \tau \omega \varsigma \tau \iota \nu \dot{\alpha} \varsigma \sigma \dot{\omega} \sigma \omega . "$

Gregory adds a note that the church built by the Neocaesareans managed to survive a major earthquake several years later, though the rest of the city was damaged. In a 2002 article, David Woods considers Gregory's account of events alongside the accounts of the earthquake preserved in other chroniclers up through the Byzantine period (D. Woods, "Gregory Thaumaturgus and the Earthquake of 344," JTS 53 (2002): 547-553).

81 J. Warren Smith explains this important stage of epectasy as follows, building a systematic formulation from Gregory's narrative account in the De vita Moysis: "The soul's recognition of God as absolute Being and ourselves as contingent beings wholly dependent upon God is the foundational understanding the soul requires in order to be reoriented from its attachment to the sensible goods of the world to its proper love of the intelligible goods of God" (J. Warren Smith, Passion and Paradise: Human and Divine Emotion in the Thought of Gregory of Nyssa, (New York, 2004), 159).

82 Albert-Kees Geljon offers a clear and concise summary of Gregory's thoughts about those human limits, writing, "On the basis of God's infinity, Gregory argues that God is incomprehensible, because only things that have a limit can be intellectually grasped. This can be called the epistemological aspect of divine infinity. A consequence is that the quest for the knowledge of God is also unending. It is prominent in $V M$, where Gregory relates it to Moses' life, explained as the unending quest for God. The human striving to know and see God is a dynamic process that never ends; it is always moving forward. God's infinity is a negative attribute of God, part of an apophatic theology. In his mystical treatises 
language. ${ }^{83}$ Within this system, the bishop's ability to articulate theological concepts (and the community's ability to comprehend his teaching) would be the primary indicator of his success. It is here that the linguistic concept of code-switching could help scholars reconsider the role of the bishop and increase our appreciation for the Life of Thaumaturgus as an important piece of evidence for Gregory's view of episcopal authority. Instead of tracking only Thaumaturgus' development and reading his life as an example of the idealized progression towards intellectual (vs. sensible) realities, attention to moments of code-switching can shift attention instead to the practical work of a bishop who must engage with real people from a range of backgrounds, on different occasions, in a variety of settings. We might think of Thaumaturgus' code-switching in Pauline terms: the bishop must be "all things to all people" (1 Cor 9:22). Because Thaumaturgus has benefited from God's adaptable pedagogy in his own life, his movement back and forth between physical demonstrations of power and speeches about doctrine or virtue is an authentic kind of switching, reflecting his combined roles as learner and educator.

\section{Conclusions}

In the final accounting, Gregory's biographical narrative was intended to serve as a catechetical tool for the Neocaesareans, while it also provided a blueprint for fourth-century bishops. Although Thaumaturgus was clearly meant to be an impressive ideal exemplar from local history, he remained accessible to Neocaesareans in the fourth-century, through Gregory's narrative. Gregory provided important commentary on the impact of Thaumaturgus' teachings for the audience learning about his life. In the midst of these three teaching episodes, Gregory focused on the concept of immediacy, such that his narrative could have offered hearers and then readers a fairly direct encounter with the wonderworker. Near the beginning of the bios, Gregory described his decision

Gregory links these two forms of infinity-God's infinity and the soul's unending quest for God - with each other" (Albert-Kees Geljon, "Divine Infinity in Gregory of Nyssa and Philo of Alexandria," VChr 59 (2005): 152-177, 167).

83 Andrew Radde-Gallwitz explains how both Basil and Gregory insist that definitions of God and Scriptural epithets for persons of the Trinity are "conceptions" that can only imperfectly convey truth about God. He illustrates clearly that the Cappadocians' focus on the limits of language emerges in part from their engagement with the thought of Eunomius. See Chapter 6, especially pages $153^{-155}$ on the distinctions between knowledge and conceptions, in A. Radde-Gallwitz, Basil of Caesarea, Gregory of Nyssa, and the Transformation of Divine Simplicity (Oxford, 2009). 
to keep "the telling of the stories about him [Thaumaturgus] ... narrative

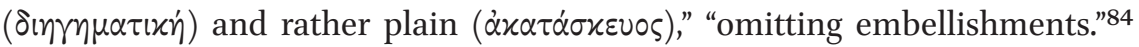
For Gregory, the simplicity proved that "remembrance of the deeds ( $\tau \dot{\eta} \nu \mu \nu \eta$ ' $\mu \eta \nu$

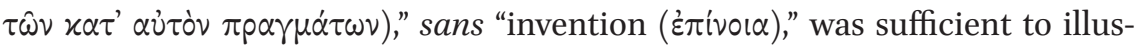
trate Thaumaturgus' greatness. The straightforward story was like "natural beauty of face, not adorned by any cunning of cosmetic art." 85 The bios held the words of his speeches and the details of his miraculous deeds; it therefore could function as a tangible record of the bishop's catechetical work. Through words, Gregory claimed to offer direct contact with the wonderworking bishop and his powerful deeds, illustrating how he himself relied on the cooperation of words and deeds in his contemporary catechetical pursuits. Like the text that Thaumaturgus used to command demons, the bios held an undeniable power to effect change in the material world.

In 1998, Andrea Sterk commented about Gregory that "because his ecclesiastical influence is generally deemed much less important than his work as a theologian, relatively little is known about his notions of leadership." ${ }^{86}$ Sterk points out, correctly, that Gregory's praise for his brother Basil and especially his portrait of Moses, with its "transformation of Moses into the image of the supreme Christian leader," helped "in propagating the monk-bishop ideal." It is indeed the norm for scholars to look primarily at Gregory's descriptions of his brother and of Moses to understand his views of Christian leadership. However, as I have attempted to demonstrate here, the biography of Thaumaturgus can offer further important insights and an additional model for the ideal bishop. For Gregory, the wonderworker's third-century life models episcopal leadership that relies on effective catechesis, pairing personal virtue with adaptability to build and strengthen a Christian community. The bios offers us a window into Christian religious training in the fourth century, including how catechists like Thaumaturgus and Gregory grappled with the tensions between invisible virtues and visible virtuous actions, between training and power, between word and deed.

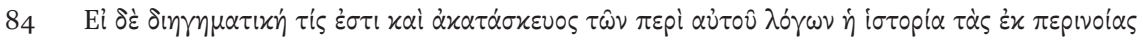

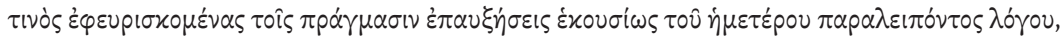

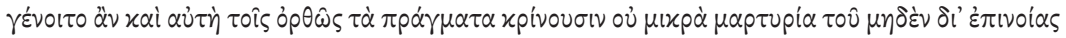

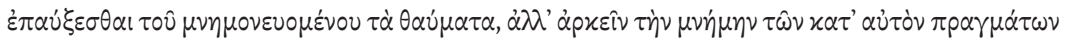

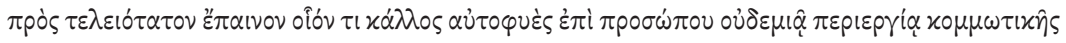

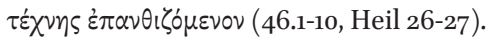

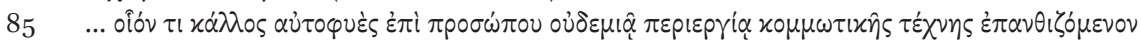
(46.8-10, Heil 27).

86 Sterk, "On Basil, Moses, and the Model Bishop," 229.

87 Sterk, "On Basil, Moses, and the Model Bishop," 230. 


\section{Acknowledgment}

I am grateful for the questions and comments I received in that venue and to Cameron Ferguson for his willingness to read and comment on an early draft. 